\title{
Physico-chemical evaluation of three varieties of tejocote (Crataegus mexicana)
}

\section{Evaluación fisicoquímica de tres variedades de tejocote (Crataegus mexicana)}

\author{
SÁNCHEZ-HERRERA, Susana†*, RODRÍGUEZ-MARTÍNEZ, Nellybeth, RODRÍGUEZ-ORTEGA \\ Alejandro and PONCE-LIRA Brenda
}

Universidad Politécnica de Francisco I. Madero. Domicilio conocido Tepatepec, Francisco I. Madero C.P.42660. Hidalgo.

ID $1^{\text {er }}$ Autor: Susana Graciela, Sánchez-Herrera / ORC ID: 0000-0002-7092-4693, Researcher ID Thomson X-2257-2018, CVU CONACYT ID: 37275

ID $1^{\text {er }}$ Coautor: Nellybeth, Rodriguez-Martinez / ORC ID: 0000-0001-7805-5958, Researcher ID Thomson: X-2132-2018. CVU CONACYT ID: 96541

ID $2^{\text {do }}$ Coautor: Alejandro, Rodríguez-Ortega / ORC ID: 0000-0002-9716-477, CVU CONACYT ID: 99817

ID $3^{\text {er }}$ Coautor: Brenda, Ponce-Lira / ORC ID: 0000-0002-4326-6242, CVU CONACYT ID: 325443

DOI: $10.35429 /$ JNAS.2019.18.6.31.38

Received March 21, 2019; Accepted June 30, 2019

\section{Abstract}

Tejocote has been used traditionally in Mexico since PreHispanic times and currently its cultivation it is considered of lesser economic importance, is distributed mainly in the States of Mexico, Puebla, Tlaxcala, Chiapas, Michoacán, Hidalgo and Morelos. The tejocote groups together more than 150 species around the world, these 93 types are in Mexico, further studies in this species are scarce. Therefore this research was the analysis of physical and chemical strains of tejocote at the Universidad Politécnica de Francisco I. Madero. The results show that the criolla variety possesses a $65.64 \%$ humidity, on the other hand the highest percentage of protein was obtained in Calpan gold variety $(3.80 \%)$, for the ether extract the criolla variety has a $41.11 \%$ fiber, criolla variety was the one that obtained the highest percentage $(16.71 \%)$, ${ }^{\circ}$ Brix criolla variety presented the higher value, which present greater weight was the Chapeado variety. This results will be a contribution to the added value given to these.

Tecojote, Fruit, Analysis

\section{Resumen}

El tejocote ha sido empleado tradicionalmente en México desde tiempos prehispánicos y actualmente su cultivo, que es considerado de importancia económica menor, se encuentra distribuido principalmente en los estados de México, Puebla, Tlaxcala, Chiapas, Michoacán, Hidalgo y Morelos. En el tejocote se agrupan más de 150 especies a nivel mundial, de éstas 93 tipos están en México, además los estudios en esta especie son escasos; por ello la presente investigación tiene como objetivo realizar el análisis físico y químico de tres variedades de tejocote en la Universidad Politécnica de Francisco I. Madero. Los resultados muestran que la variedad criolla posee un $65.64 \%$ de humedad, por otra parte el mayor porcentaje de proteína se obtuvo en la variedad Calpan gold $(3.80 \%)$, para el extracto etéreo la variedad criolla tiene un $41.11 \%$, en cuanto a fibra la variedad criolla fue la que obtuvo el mayor porcentaje $(16.71 \%)$, para ${ }^{\circ}$ Brix la variedad criolla fue la que presento el valor más alto, el que presento mayor peso fue la variedad Chapeado. Estos resultados serán aportación para el valor agregado que se le dé a estas 3 variedades.

Tejocote, Fruto, Análisis

Citacion: SÁNCHEZ-HERRERA, Susana, RODRÍGUEZ-MARTÍNEZ, Nellybeth, RODRÍGUEZ-ORTEGA Alejandro and PONCE-LIRA Brenda. Physico-chemical evaluation of three varieties of tejocote (Crataegus mexicana). Journal of Natural and Agricultural Sciences. 2019, 6-18: 31-38.

*Correspondence to Author (ssanchez@upfim.edu.mx)

$\dagger$ Researcher contributing first author 


\section{Introduction}

The Crataegus genus consists of about 15 species in Mexico and is distributed in most of the mountainous areas of the country (Núñez Colín et al. 2008). The common name that Crataegus species receive in Mexico is "tejocote", a name that derives from the Nahuatl "texócotl", which means hard and sour fruit (Patrick Barry, cited by Tukey, 1964), to which medicinal properties are attributed since preHispanic times, being used in traditional medicine, for the treatment of various respiratory diseases, such as: flu, cough, asthma, bronchitis, etc. (Arrieta et al., 2010).

The fruit of tejocote has been traditionally used in Mexico since pre-Hispanic times and currently its cultivation, which is considered of minor economic importance, is distributed mainly in the states of Mexico, Puebla, Tlaxcala, Chiapas, Michoacán, Hidalgo and Morelos (Nieto y Borys, 2008).

From the cultural and commercial point of view, it is used in the celebrations of "all saints" and in Christmas for the elaboration of punches and filling of piñatas (Borys and Leszczyñska-Borys, 1994; Núñez-Colín, 2009) and it has been demonstrated that the fruit has a high content of vitamins, minerals and pectins (Núñez-Colín, 2009).

The tejocote belongs to the Crataegus genus, 95 species are found in the Americas, 13 of which are recognized to exist in Mexico, some endemic (Phipps, 1997). Crataegus species are distributed throughout the world, including Europe, the Middle East, East Asia, North America, but only in the Northern Hemisphere with atypical points in Peru and Ecuador (Phipps, 1997; Phipps et al., 2003).

In Mexico, tejocote is distributed in the mountainous areas of the Sierra Madre Oriental (Coahuila, Nuevo León, Tamaulipas, San Luis Potosí and Hidalgo), Sierra Madre Occidental (Durango and Chihuahua), the Sierra Madre del Sur (Oaxaca and Los highlands of Chiapas), and the Neo Volcanic Axis (Veracruz, Puebla, State of Mexico, Morelos, Jalisco and Michoacán) (Phipps, 1997; Pérez et al., 2004).
In the tejocote more than 150 species are grouped worldwide, of these, 95 are in America, in Mexico, there are five commercial varieties: 1.-Early or the gracilar Crataegus. This cultivar is registered in the germplasm bank as accession number 66 with code EM66-SCM03, taxonomically identified within the C. gracilior Phipps species. It was collected in Santa Catarina del Monte, state of Mexico, presents an elliptical cup, a height of 3.56 meters, presents 8 small spines per vegetative bud, small leaves; 3.20 styles per flower of 0.89 centimeters on average, 19.40 stamens, medium pale yellow fruits, high soluble solids content $\left(16.0^{\circ}\right.$ Brix $)$ and a mooring of 54.28 fruits per reproductive bud; its fruiting time is between the months of July to September (Nieto, et. al., 2008).

2.-Calpan Gold. This cultivar is registered in the germplasm bank as accession number 86 with code P86-HUE10, taxonomically identified within the species C. mexicana Moc. \& Sessé. It is grown mainly in Huejotzingo, Puebla, has a circular cup, a height of 4.3 meters, has few thorns in some young vegetative shoots; large leaves; 2.3 styles per flower of 0.53 centimeters on average, 21.8 stamens, large orange-yellow fruits, low soluble solids content $\left(8.75^{\circ}\right.$ Brix) and a mooring of 35.50 fruits per reproductive bud; its fruiting season is between the months of November to February.

3.-Eli or Crataegus stipulosa, its cup is circular of 4.5 meters in diameter has large spines of $3.5 \mathrm{~cm}$ and its fruits are intense red, they are of reproductive sprout its season is from August to November. This cultivar is registered in the germplasm bank as accession number 83 with code CH83-SCC09, taxonomically identified within the species C. stipulosa (HBK) Steud. It was collected in San Cristóbal de las Casas state of Chiapas, presents a circular cup, a height of 4.5 meters, presents 3.67 large spines per vegetative bud, small leaves; 3.22 styles per flower of 0.49 centimeters on average, 18.81 stamps, small fruits of intense red color, medium content of soluble solids $\left(13.37^{\circ}\right.$ Brix $)$ and a mooring of 45.17 fruits per reproductive bud; its fruiting time is between the months of August to November (Nieto, et. al., 2008). 
4.- Centenary or Crataegus nelsoni Eggl. This cultivar is registered in the germplasm bank as accession number 18 with code $\mathrm{CH} 30 \mathrm{C}$ RRO03, taxonomically identified within the species C. nelsoni Eggl. It was collected in Rancho Robelo, San Cristóbal de las Casas state of Chiapas; it presents an elliptical cup, a height of 2.73 meters, presents 2.33 large spines per vegetative sprout, small leaves; 4.40 styles per flower of 0.92 centimeters on average, 19.20 stamens, small scarlet red fruits, high soluble solids content $\left(15.20^{\circ}\right.$ Brix $)$ and a mooring of 58.72 fruits per reproductive bud; its fruiting time is between the months of September to December (Nieto, et. al., 2008).

5.- Chapeado or Crataegus mexicana Moc \& sessé. This cultivar is registered in the germplasm bank see HPC100-HUE12, taxonomically identified as accession number 100 within the species C. mexicana Moc. \& Sessé. It was collected in Huejotzingo state of Puebla; It has a semicircular cup, 4.6 meters high, no spines, large leaves; two styles per flower of 0.53 centimeters on average, 19.6 stamens, large orange fruits with a slight red veneer, low soluble solids content $\left(8.53^{\circ}\right.$ Brix $)$ and a mooring of 11.78 fruits per reproductive bud; its fruiting time is between the months of October to January (Nieto et. al., 2008).

The tejocote of greater diameter and greater commercial value is the tejocote "Chapeado", the tejocote of smaller diameter and less commercial value called Tejocote of third class or "Criollo" and the tejocote of second class or of intermediate size between the Chapeado and the Creole and what is called "Segundita".

The tejocote is often grown in family gardens or on the banks of farmland, on hillsides with steep topography (60\% slope) in ravines, and in growing areas. Inhabits oak, pine, pineoak and Abies forests; frequently in secondary communities. They favor acid and frank soils. It develops in black, clayey, stony soils of sedimentary and volcanic origin. It is located at altitudes ranging from 400 to 3,000 meters above sea level; They are classified into Creole and cultivated types; the former are located between 14 and $32^{\circ}$ north latitude, and the second between 19 and $20^{\circ}$ north latitude (Nieto and Borys, 1993).

\section{Uses of tejocote}

The tejocote has been given multiple uses, among them as livestock feed, ornamental plant and in the food industry (Nieto and Borys, 1993; Barrientos and López, 1995).

The tejocote is preferably appreciated at Christmas times due to its use in the elaboration of the punch, traditional drink associated with Mexican inns.

The fruits can be eaten raw and used dried or cooked, canned, jellies and jams. Several species of tejocote are recognized for their medicinal properties; The fruits and flowers of many hawthorn are well known in folk medicine as cardiac tonic, properties that are documented (Hadjimitsi and Zabetakis, 2005; Dinesh et al., 2012).

In our country, flowers, leaves and fruits are used to relieve cough and is also used as a sedative; the root bark, as a diuretic for kidney diseases, to control the formation of varicose veins, weight and cholesterol; and the root and fruits for diabetes (Martínez, 1967). Additionally, it is used as a cardiac tonic, to improve circulation, angina pectoris and abdominal pain and to control hypertension (Ody, 1993).

\section{Nutritional Value of Tejocote}

Nutritionally, tejocote is of great importance due to its sugar content, mainly glucose, acids (citric, quinic, malic) (Liu, et al., 2009); fiber mainly as pectin, antioxidants (bioflavonoids and proanthocyanidins) (Tassell et al., 2010), carotenoids, vitamin $\mathrm{C}$, and $\mathrm{B}$ vitamins (Higareda et al., 1995) and for their therapeutic properties in cardiovascular diseases (Tassell et al. ., 2010) and pulmonary (Özcan et al., 2005). Edwards et al. (2012) in their review on the chemistry of the Crataegus genus mention some quantified sugars in fruits of different species of tejocote, the most abundant sugar being fruitful, (Urbonaviciute et al. 2006 cited by Edwards et al, 2012). Other components mentioned in the aforementioned work are acidic, among them and of greater abundance, citrus and malic acid stand out, which have been shown to have a number of functions outside their role in the primary metabolism of the plant, including tolerance to aluminum and phosphorus absorption regulation. 
Likewise, the presence of terpenes, hydroxycinnamic acids, flavonoids and a large number of chemical compounds identified in at least 27 different species and two hybrids native to Europe, Asia, and North America are reported. It is a fruit rich in vitamin $\mathrm{C}$, carotenes and mineral salts, including calcium, phosphorus, iron and has a high pectin content.

In Mexico, the chemical studies of Crategus have mainly been directed to the study of flavonoids and phenols. Phenolic compounds such as proanthocyanidins, catechins, flavonoids (Nuñez et al., 2007; García et al., 2013) and phenolic acids (chlorogenic acid) have been identified in tejocote associated with their antioxidant activity (Bahorum et al., 1994) . Garcia et. al., (2013) evaluate the content of phenolic compounds, flavonoids and vitamin $\mathrm{C}$ associated with antioxidant activity in the fruits of 20 accessions that are located in Mexico.

In general, the fruit is characterized by containing a humidity of $82 \%$ and $12 \%$ carbohydrates, in addition to $2.0 \%$ ash, $2.6 \%$ pectin and provides a total of 61.4 calories (Martínez, 1952).

From a sample of $100 \mathrm{gr}$ of fruit as pulp according to data from the National Institute of Nutrition, its high value in vitamin A (424.4 mg. Eq. Retinol), ascorbic acid (46 mg), iron and calcium, as well as its content in pectins.

Regarding the analysis of the complete dehydrated fruit that is used for the production of flour, it is important to note its high carbohydrate and raw fiber content of both good quality fruit and that of those residues from the production of jelly, tie, jam, nectar etc., since its use would be of great interest through a zootechnical evaluation or even, could be used for human consumption.

In the case of ashes, these fluctuate between $1.59 \%$ and $2.97 \%$, where minerals such as sodium, potassium, calcium and magnesium predominate, although the presence in greater or lesser proportion of these elements depends on the type of soil and cultural work that in are made. The chemical composition of a fruit varies according to the botanical variety, the cultivation practices, the atmospheric state and the degree of maturity. Most fruits with high concentration of water and carbohydrates and low in protein and carbohydrates.
The importance of tejocote is for its nutritional use; as rootstock of the same tejocote, apple tree, pear tree, quince tree and loquat; ecological; ornamental; fodder medicinal and industrial (Flores, 2007).

Therefore, the objective of this research was to perform the analysis of ash, moisture, fat, protein and fiber of the Chapeado, Calpan Gold and Criolla varieties harvested in the fruit growing area of the Polytechnic University of Francisco I. Madero.

\section{Methodology}

The plant material is found in the fruit growing area of the Polytechnic University of Francisco I. Madero (figure 1) located in the town of Tepatepec, in the Municipality of Francisco I. Madero, in the State of Hidalgo, with the following Latitude coordinates : $20^{\circ} 13$ ' 39.53 ' 'N., Longitude: $99^{\circ} 5^{\prime} 23.31$ " Or, the analyzes were also performed in the analytical chemistry laboratory of the same institution.

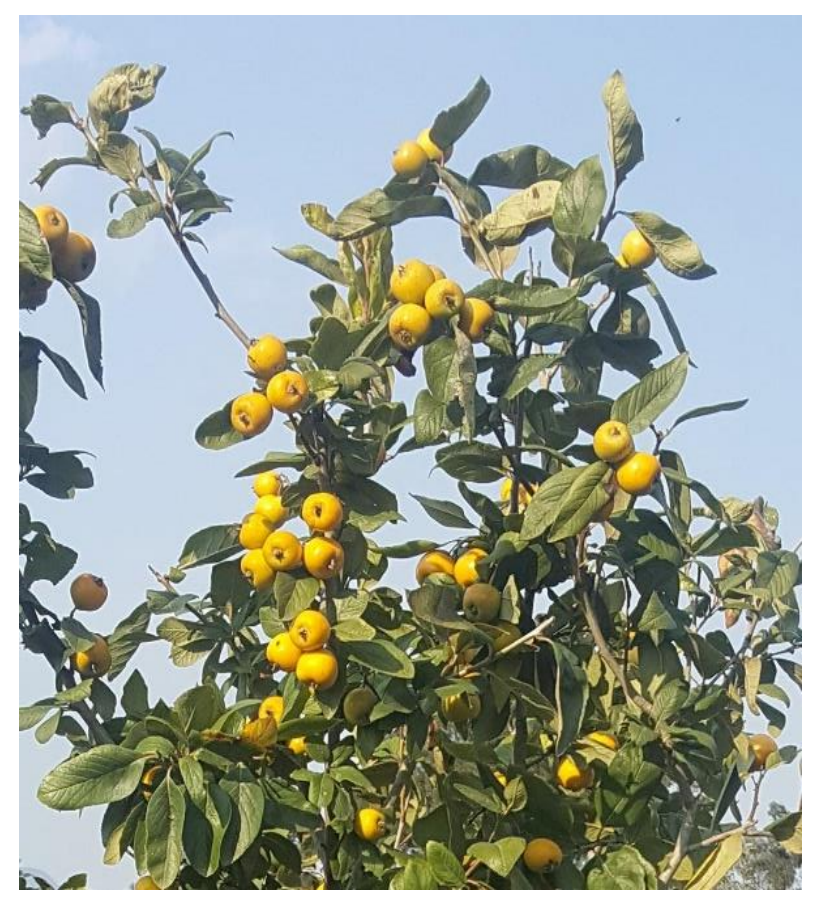

Figure 1 Vegetal material

\section{Collection of biological material}

The collection of $1 / 2 \mathrm{~kg}$ of each of the varieties: Chapeado, Calpan Gold and Criollo was carried out and placed in paper bags to be transferred to the laboratory. 


\section{Sample Preparation}

The pulp was separated from the rest of the fruit with a Marca, Migsa model GS.JES game extractor and placed in the freezer at $-4^{\circ} \mathrm{C}$ before starting the analyzes.

\section{Moisture determination}

To determine moisture, a sample of $1 \mathrm{~g}$ each variety was taken with two repetitions, and placed in an OHAUS ${ }^{\circledR}$ brand thermobalance at a temperature of $105^{\circ} \mathrm{C}$ for 40 minutes. Subsequently, the sample was removed and the final sample weight was measured.

\section{Ash Determination}

For ash determination, $0.5 \mathrm{~g}$ of sample from each variety was taken with three repetitions, placed in a previously tared crucible, the crucible was placed with the sample in the flask for 3 hours, at a temperature of $550^{\circ} \mathrm{C}$. Subsequently the crucible with the calcined sample was transferred to the desiccator; until reaching room temperature and the crucible was weighed. Subsequently the corresponding calculations were made according to the following formula:

$\%$ of ashes $=\frac{\mathrm{Pf}-\mathrm{Pc}}{\mathrm{Pm}} \quad x 100$

Where:

$\mathrm{Pf}=$ Final weight with the calcined sample, in grams.

$\mathrm{Pc}=$ Constant weight of the crucible.

$\mathrm{Pm}=$ Sample weight, in grams.

\section{Fat determination}

For the determination of fat, $3 \mathrm{~g}$ of sample were taken and placed in a filter paper cartridge previously defatted and dehydrated, then it was introduced into the extraction chamber of the soxhlet equipment and $250 \mathrm{ml}$ of hexane was added and the extraction was carried out for 10 cycles, the sample was placed in the oven for a period of 10 minutes at a temperature of $105^{\circ} \mathrm{C}$ for the removal of solvent residues. The calculations were expressed as a percentage according to the difference in weight.

$\%$ of ethereal extract $=\frac{\mathrm{Pi}-\mathrm{Pf}}{\mathrm{Pi}} \quad x 100$
Where:

$\mathrm{Pi}=$ Initial weight of the sample, in grams.

$\mathrm{Pf}=$ Final weight.

$\mathrm{Pi}=$ Initial weight of the sample, in grams.

\section{Fiber determination}

For the determination of raw fiber, 1 gram of sample was taken for each variety with two repetitions. The dehydrated and degreased sample is treated with $200 \mathrm{ml}$ boiling sulfuric acid for 30 minutes to subsequently filter under vacuum, rinsed with hot water, and the residue is collected and then digested with $200 \mathrm{ml}$ boiling sodium hydroxide for 30 minutes, subsequently filtered under vacuum and rinsed with hot water and ethanol. The residue was subjected to calcination at $550{ }^{\circ} \mathrm{C}$, the residue - ash difference is considered raw fiber. Subsequently, the calculations were performed using the following formula:

$\%$ raw fiber $=\frac{\text { Weight }(\mathrm{MRD})-\text { Ash weight }}{\text { Initial sample weight }} \times 100$

$(\mathrm{MRD})=$ Digestion Resistant Sample

\section{Protein determination}

For the determination of protein, $0.5 \mathrm{~g}$ of each variety was taken with three repetitions. A food grade PVC plastic film of a size of $5 \times 5 \mathrm{~cm}$ was cut, in which it was placed in a watch glass where $5 \mathrm{~g}$ of sample and $2 \mathrm{~g}$ of reactive mixture were added; subsequently it was closed and placed in a digestion tube with $10 \mathrm{ml}$ of sulfuric acid and subsequently placed in the digester for 1 hour, after the time the digestion tubes were allowed to cool to room temperature and $20 \mathrm{ml}$ of distilled water was added, $40 \mathrm{ml}$ of $40 \%$ $\mathrm{NaOH}$ and $25 \mathrm{ml}$ of $4 \% \mathrm{H} 3 \mathrm{BO} 3$ with 3 drops of methyl red and titrated with $0.1 \mathrm{~N} \mathrm{HCl}$.

Subsequently, the calculations were performed using the following formula:

$\% N=\frac{[(m l d e H C L)(N \text { del } H C L)(1.4)]}{\text { Sample weight }} \times 100$

\section{Determination of pH and Brix degrees}

For the determination of $\mathrm{pH} 1 \mathrm{gr}$ of sample of each variety was taken with three repetitions. The sample was placed in a beaker in which $1 \mathrm{ml}$ of distilled water was added to subsequently mix the sample. 
For the determination of Grades ${ }^{\circ}$ Brix a "master refractometer" was used, with 1 gr of sample of each variety with three repetitions.

\section{Results}

The analysis of moisture, ashes, protein, ethereal extract and fiber was performed in three varieties of Mexican Crataegus tejocote. Each analysis was done in triplicate in each of the samples. Table 1 shows the average of the results obtained from each variety of tejocote.

\begin{tabular}{|l|r|r|r|}
\hline Analysis / Varieties & Veneered & \multicolumn{2}{c|}{$\begin{array}{c}\text { Calpan } \\
\text { Gold }\end{array}$} \\
\hline (\%) Humidity & 64.69 & 61.71 & 65.64 \\
\hline (\%) Ashes & 2.97 & 2.71 & 2.38 \\
\hline (\%) Protein & 2.85 & 3.80 & 2.87 \\
\hline $\begin{array}{l}\text { (\%) Ethereal } \\
\text { Extract }\end{array}$ & 39.39 & 36.64 & 41.11 \\
\hline $\begin{array}{l}\text { (\%) Fiber } \\
\text { pH }\end{array}$ & 15.11 & 12.78 & 16.71 \\
\hline${ }^{\circ}$ Brix & 3.85 & 4.30 & 3.80 \\
\hline Average Weight $(\mathrm{g})$ & 10.33 & 10.67 & 11.00 \\
\hline $\begin{array}{l}\text { Average Diameter } \\
(\mathrm{cm})\end{array}$ & 3.23 & 13.79 & 6.11 \\
\hline
\end{tabular}

Table 1 Results of the main nutritional components of tejocote

The table shows that the Creole variety has a percentage of $65.64 \%$ humidity, while Calpan gold presented the lowest percentage with $61.71 \%$. As for the $\%$ of ashes, the veneered variety contains $2.97 \%$, while in the Creole tejocote the lowest percentage was obtained with $2.38 \%$, these data are lower than those presented by Higareda, et.al. (1995) where $82 \%$ values are reported.

The Calpan gold variety presents the highest percentage of protein with $3.80 \%$, while the one with the lowest percentage was the tejocote veneered with $2.85 \%$. These data obtained are slightly higher than those presented by Higareda et al (1985), where values of $1.58 \%$ were found.

In the percentage of ethereal extract, the Creole fruit contains $41.11 \%$, while the Calpan gold variety was the one with the lowest percentage with $36.64 \%$, these data were much higher than those presented by Higareda et al in 1985, where they obtained a $0.09 \%$ value. Regarding the percentage of fiber, the fruit of Creole tejocote presented $16.71 \%$, while the Calpan gold variety has the lowest percentage with $12.78 \%$.
In the case of $\mathrm{pH}$ values, a range from 3.8 to 4.3 was obtained, which indicates that the pulp is acidic, these data are similar to those presented by Franco-Mora, et al., In 2009 where they obtain an average of 3.31. You will know where I take the master bibliography I could not find it Finally in the measurement of oBrix, the Creole tejocote reaches 11.00 units, while the veneered variety has 10.33 units. The values obtained in the present studies are higher than those reported by Nieto et al., (2008), where for the Calpan Gold variety they reach $8.75^{\circ}$ Brix and $8.53^{\circ}$ Brix for the Chapeado variety, this possibly at the growth conditions of the species.

The highest weight per fruit was presented by the Chapeado variety, as shown in Figure 2, while the Creole tejocote has a lower weight per fruit, and the size of the diameter of each variety is directly related to the weight of each one..

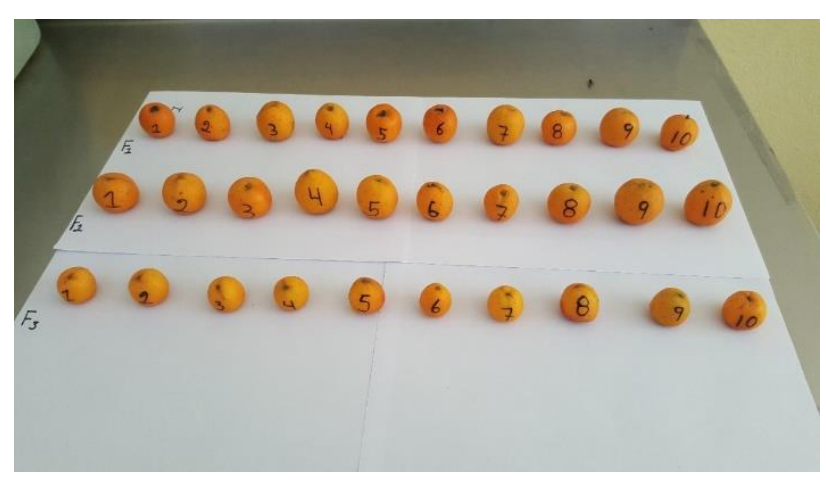

Figure 2 Tejocote F1 phenology, (Calpan gold) F2, (Veneered) F3, (Creole)

\section{Conclusions}

The results show that the Creole variety has $65.64 \%$ moisture, on the other hand the highest percentage of protein was obtained in the Calpan gold variety $(3.80 \%)$, for the ethereal extract the Creole variety has $41.11 \%$, in terms of fiber the Creole variety was the one that obtained the highest percentage $(16.71 \%)$, for ${ }^{\circ}$ Brix the Creole variety was the one with the highest value, the one that presented the greatest weight was the Chapeado variety. Therefore, the use of each variety depends on what the producer wishes to obtain.

\section{References}

Arrieta, J., Siles B., D., García S., J., Reyes T., B., Sánchez M., M. E. (2010). Relaxant effect of the extracts of Crataegus mexicana on Guinea Pig tracheal smooth muscle. Pharmacognosy Journal 2(17):40-46.

SÁNCHEZ-HERRERA, Susana, RODRÍGUEZ-MARTÍNEZ, Nellybeth, RODRÍGUEZ-ORTEGA Alejandro and PONCE-LIRA Brenda. Physico-chemical evaluation of three varieties of tejocote (Crataegus mexicana). Journal of Natural and Agricultural Sciences. 2019 
Bahorun, T., Trotin, F., Pommery, J., Vasseur, J., Pinkas, M. (1994). Antioxidant activities of Crataegus monogyna extracts. Planta Medica, 60, 323-328.

Barrientos V., A., López A., A. (1995). Características hortícolas y viverísticas de tejocote (Crataegus pubescens (H.B.K.) de la república Mexicana. Tesis Profesional. Departamento de Fitotecnia. Universidad Autónoma Chapingo. México. $72 \mathrm{p}$

Borys, M. W. y Leszczyñska-Borys, H. (1994). Tejocote (Crataegus spp.) planta para solares, macetas e interiores. Revista Chapingo. Serie Horticultura. 1:95-107.

Dinesh, K., Vikrant A., Zulfi Q., Ali B., Nisar A.K., Deo N.P. (2012). The genus Crataegus: chemical and pharmacological perspectives. Rev. Bras. Farmacogn. Braz. J. Pharmacogn. 22(5): 1187-1200.

Edwards, J. E., Brown, P. N., Talent, N.; Dickinson, T. A., Shipley, P. R. (2012). A review of the chemistry of the genus Crataegus. Phytochemistry 79: 5-26.

Flores B., P. A. (2007). Pectina de tejocote. Colegio Francés Hidalgo.1-4 pp.

Franco-Mora, O., Aguirre-Ortega, S., MoralesRosales, E.J., González-Huerta, A., GutiérrezRodríguez, F. (2010). Caracterización morfológica y bioquímica de frutos de tejocote (Crataegus mexicana DC.) de Lerma y Ocoyoacac, México. Ciencia Ergo Sum, 17 (1,): 61-66 pp.

García M., R., Nieto A., R. (2012). Valor nutracéutico del tejocote (Crataegus spp.) de México. SINAREFI-SAGARPA-UACH. 63 p.

Higareda, R.A., Salazar, J. A., Ramos, E. G. (1995). Conservación postcosecha del tejocote (Crataegus mexicana). Revista Chapingo. Serie Horticultura 4: 161-163.

García M., R., Aguilar S., L., Soto H., M., Nieto A.R., Kite., G. (2013). Flavonoids and antioxidant activity of flowers of Mexican Crataegus spp. Natural Products Research 27 (9): 834-836.

García M., R., Ibarra E.E., Nieto A., R. (2013). Antioxidant compounds in hawthorn fruits (Crataegus spp.) of Mexico. Revista Mexicana de Biodiversidad 84 (4): 1298-1304.
Hadjimitsi, E., Zabetakis, L. (2005). The aroma of jam prepared from fruits of mosphilla (Crataegus azarolus L.). Flavour and Fragance Journal 20:507-511.

Liu, P., Kallio, H., Lu, D., Zhou, C., Ou, S., \& Yang, B. (2009). Acids, sugars, and sugar alcohols in Chinese hawthorn (Crataegus spp.) fruits. Journal of Agricultural and Food Chemistry 58 (2): 1012-1019.

Martínez, M. (1967). Las Plantas Medicinales de México. $6^{\circ}$ Ed. Editorial Botas. México. 657 p.

Martínez M. (1952). Plantas Útiles de la Flora Mexicana. Edición Botas. México.

Nieto A., R., Borys, M. W. (1992). Banco de Germoplasma de tejocote (Crataegus spp.) de la República Mexicana. Revista Chapingo. 16(77): 126-130.

Nieto A., R., Borys, M. W. (1993). El tejocote (Crataegus spp.); un potencial frutícola de zonas templadas. Revista Fruticultura Profesional. 54:63-71.

Nieto, A. R. y Borys M. W. (2008). Germoplasma y usos del tejocote en México En: J. G. Cruz C. y P. A. Torres L. (Comps.). Enfoques tecnológicos en la fruticultura. Un tributo a Raúl Mosqueda. UACH. México.

Nieto, A. R; Borys, W.M y Nuñez, C.C. (2008). Variedades comerciales de tejocote. Extensión al Campo. Chapingo. 10-16 p.

Nuñez C.C., García M.R., Nieto A.R. (2007). Caracterización de genotipos de Crataegus en relación al contenido de compuestos fenólicos. Proceedings Interamerican Society Tropical Horticulture 51: 126-127

Núñez-Colín, C.A., Nieto-Ángel, R., BarrientosPriego, A.F., Sahagún-Castellanos, J., Segura, S., González-Andrés, F. (2008). Variability of three regional sources of germplasm of Tejocote (Crataegus spp.) from central and southern Mexico. Genet. Resources Crop Evol. 55:11591165.

Núñez-Colín, C. A. (2009). The tejocote (Crataegus species): a Mexican plant genetic resources that is wasted. A review. Acta Hortic. 806:339-346. 
Ody, P. (1993). The Herb Society's Complete Medicinal Herb. Dorling Kindersley. U K.51 p.

Özcan, M., H. Hacseferoğullari, M. T. y Arslan D. (2005). Hawthorn (Crataegus spp.) Fruit: Some Physical and Chemical Properties. Journal of Food Engineering. 69:409-413

Pérez O., Nuñez C, Segura, S., Nieto A.R., Barrientos A. F. (2004). Los recursos genéticos de Crataegus (Rosaceae) en México: Variación eco-climática. Proceedings of the Interamerican Society for Tropical Horticulture 48:149-151

Phipps. J. B. (1997). Monograph of northern Mexican Crataegus (Rosaceae, Subfam. Maloideae). SIDA Botanical Miscellany 15:194.

Phipps. J. B., O'kennon R. J., Lance R. W. (2003). Hawthorns and Medlars. Plant Collector Guide. Royal Horticultural Society. Timber Press. Portland, USA. 139 p.

Tassell, M.C., Kingston, R., Gilroy, D., Lehane, M., \& Furey, A. (2010). Hawthorn (Crataegus spp.) in the treatment of cardiovascular disease. Pharmacognosy reviews, 4(7): 32.

Tukey, H. B. (1964). Dwarfed Fruit Trees. McMillan Co. Inc. New York, N. Y. pp. 182194. 